\title{
The 2007-2009 Financial Crisis and Executive Compensation: Analysis and a Proposal for a Novel Structure
}

Alon Raviv* and Yoram Landskroner**

June 15, 2009

JEL classification: G12, G13, G21, G28, G38, E58.

Keywords: compensation practices, executive compensation, excessive risk taking, executive stock options, financial crisis

* Corresponding author: Alon Raviv, Brandeis University, International Business School, Mailstop 32, Waltham, MA 02454-9110, Tel: +1 (617)3580005. E-mail: $\underline{\text { araviv@brandeis.edu }}$

** The School of Business, The Hebrew University and the Stern School of Business, New York University, 44 West Fourth Street, New York, NY 10012, U.S.A. Tel +1 212-998-0445, Fax +1 $212-$ 995-4220. E-mail: ylandskr@stern.nyu.edu 


\begin{abstract}
During the 2007-2009 crises financial institutions have come under increasing pressure from regulators, politicians and shareholders to change their compensation practices in order to remove the incentive for short term excessive risk taking.

In this paper we analyze first how the common executive compensation, which is composed of equity-based compensation (stocks and executive stock options) and a fixed cash compensation, leads to a concave relationship between assets risk and compensation value and creates an incentive for the executive to choose corner solutions that either lead to an excessive risk taking or to a freeze out of the lending activity to the public.

This paper's main contribution is a novel component, for executive compensation, that is paid only if the value of the firm assets is located in some predetermined range. This new form of compensation motivates the executive to take an intermediate (internal solution) level of assets risk because of the convex relationship between assets risk and compensation value.
\end{abstract}




\section{Introduction}

Financial intermediaries, particular commercial banks, are special because of their economic functions, which include: asset transformation, delegated monitoring and the provision of liquidity. An essential part of banking involves risk taking, this is beneficial to the economy up to a point of "excessive risk" taking that can be detrimental. Major developments in capital markets in recent years, such as globalization, consolidation and financial innovation, have increased uncertainty in financial markets and therefore risk taking and its management have became a major concern for financial institutions. Examples are the Basel accords which concentrate on banking risks (mainly credit) and capital adequacy of banks ${ }^{1}$

The 2007-2009 financial crisis was caused by a number of factors one of them being excessive risk taking by financial institutions. This excessive risk taking took on different forms, including: origination of subprime ARMs structured to systematically default or be refinanced; holding on excessively large amounts of ABS; increased leverage ratios (off-balance) and writing huge volumes of out-of-the-money put options (CDS). These actions contributed to a credit boom and housing bubble that burst in 2007. Risk taking was exacerbated by institutions that were subject to moral hazard because of government explicit (deposit insurance) or implicit (to-big-to-fail) guarantees

This increased motivation for risk taking by financial institutions can be explained by the rapid growth of executive equity based compensation in recent years. Between 1993 and 2003, equity-based compensation has increased considerably, but this growth was not accompanied by a substitution effect, that is a reduction in non-equity compensation (Gabaix and Landier 2008, Bebchuk and Grinstein 2005). There is also 
evidence for that option grants closely track stock market indices while CEO cash compensation is weakly correlated with the Dow-Jones Average, so that CEO total compensation is strongly correlated with the stock market (Hall and Murphy 2003). According to agency theory, equity based compensation (stocks or stock options) is positively related to the underlying stock variance and therefore motivates executives to take higher levels of risk, which would be more acceptable to shareholders (Jensen and Meckling 1976 and Hirshleifer and Suh 1992). Empirical studies have provided support to the agency theory hypothesis (Agrawal and Mandelker 1987, DeFusco et al. 1990, Guay 1999 and Coles et al. 2008). Moreover, there is evidence that following deregulation, banks have increasingly employed stock option-based compensation and as a result the structure of executive compensation induced more risk-taking (Chen et al 2006). ${ }^{2}$

At the initial stage of the 2007-2009 financial crises financial institution came indeed under increasing pressure from regulators, politicians and shareholders to change their executive pay structure to remove the incentive for short term excessive risk taking. Congress imposed restrictions on pay arrangements on all financial firms that receive funds from the federal government's Troubled Asset Relief Program (TARP). However at the later stages of the crisis the opposite problem happened: A "flight to quality" took place and financial institutions tightened lending standards, which resulted in a credit crunch for businesses and households. The U.S government (U.S. Treasury and Federal Reserve) engaged in large unprecedented efforts to unfreeze the credit markets and renew the flow of bank loans to the public. ${ }^{3}$ However, the Treasury has been criticized by many for not having given clear guidance regarding the type of the optimal new executive 
compensation. ${ }^{4}$ Moreover, critics claimed that although hundreds of billions of dollars were injected into the marketplace there has been no demonstrable effect on lending to households and businesses. ${ }^{5}$

This paper employs an option approach to show that a compensation scheme that includes options and cash to be paid if the firm remains solvent, will lead to corner solutions by the manager, who will choose either the lowest or the highest possible level of risk, depending on the value of the assets (which are assumed to depend on the state of the economy: whether in a boom or a recession). We show that a compensation package that combines equity based compensation and risky cash would not incentivize the executives to take a moderate level of risk because of the concave relationship between assets volatility and the value of total compensation. The current freeze in the credit market can be explained by the negative incentive of executives to increase assets risk. This negative incentive for risk taking is the result of the decline in the value of the assets of financial institutions which cause the cash compensation to dominate the equity-based compensation. We show that in such a state the value of the executive compensation decreases with the level of assets risk. Therefore the executive is motivated to choose the minimum possible level of assets risk. The expected result is that executives of financial institution would not substitute the relative low risk of say government debt with risky loans to businesses and households.

This paper's main contribution is a proposed new compensation component in the executive compensation structure. Unlike existing compensations forms this one motivates the executive to take a moderate level of assets risk and thus enhancing financial stability by discouraging financial institutions from taking excessive risks 
during boom times while avoiding the negative incentive for risk taking by the financial institutions and speeding up financial recovery in a crisis. ${ }^{6}$

The suggested executive compensation includes, as in the traditional executive compensation package, a fixed payment that is paid as long as the company is solvent, an option-based compensation that increases with the value of assets and a new compensation in the form of a fixed payment, that is paid upon maturity if the value of the firm assets is between two upper thresholds..

The new component of the executive compensation has a payoff identical to that of a combination of a long "cash-or nothing" call option (i.e., binary option) that pays fixed amount of money at maturity if the value of assets is above some upper threshold, and a short position in a similar option with a higher strike price. The compensation value is bell-shaped with respect to assets volatility. Therefore, because of the convex relationship between the total value of the two options and volatility their maximum would be reached at some interior level of volatility and not as a corner solution of zero or infinity.

The model presented is related to papers that try to find ways to reduce the risk taking incentives of stockholders and executives. These measures include bond covenants (Smith and Warner 1979), shorting debt maturity (Barnea et al 1980, Barclay and Smith 1995 and Guedes and Opler 1996), bank borrowing (Diamond 1989, 1991) .Our paper is also related to works that analyze corporate securities that can reduce assets substitution and therefore deter executives from taking excessive risks (Green 1984 and Chesney and Gibson-Asner 2001). 
The remainder of the paper is organized as follows. Section 2 presents the basic model for the valuation of executive compensation under a traditional compensation structure. Section 3 analyzes executive compensation and incentives in good times (the bubble of 2004-2007) and then analyzes executive compensation and incentives in bad times (the crises of 2007-2009). Section 4 presents the new suggested executive compensation component and analyzes its sensitivity to assets risk. Section 5 concludes the paper with a summary.

\section{The analysis of executive compensation and its risk taking incentives}

In this paper's valuation process of the financial institutions' securities is followed through an option-based structural model of credit as developed by Merton's (1974). Specifically we consider a hypothetical financial institution with assets that are continuously traded in an arbitrage free and complete market with riskless borrowing and lending at a constant rate $r$. The value of the bank's assets, denoted by $V$, is independent of its capital structure, and is well described under the risk neutral probability by the following stochastic differential equation:

$$
d V=(r-\delta) V d t+\sigma V d W
$$

where $W$ is a standard Brownian motion, $\delta$ is the institution's payout ratio and $\sigma$ is the instantaneous constant standard deviation of the assets' rate of return. ${ }^{7}$ 
We assume that initially the financial institution is financed by two types of securities. The first is a single zero-coupon deposit with a face value of $F^{D}$ that is held by a depositor. The deposit is the most senior security, and thus has priority over all other classes of securities. The second security is a residual equity claim with a market value denoted by $S$. It is next assumed that the bank encounters some financial distress due to poor performing assets. The government "bails out" the institution by purchasing some troubled assets in return for preferred stock. This junior debt/ preferred stock has a face value of $F^{P}$ and it is subordinated to the senior deposit in the event of bankruptcy.

We assume that during the time horizon $T-t$, between the current time and debt maturity, the firm does not depart from its ex ante investment policy and thus the executive's choice of volatility is made at the beginning of the period (at time 0 ) with the main objective of maximizing the value of her compensation. This objective does not necessarily coincide with the firm value maximization or with the stockholders' value maximization. The executive compensation has two elements. The first is a fixed payment, which is paid as long as the firm is solvent. The second element is a variable component made up of executive stock options that depend on the performance of the financial institution as measured by its common stock prices or some other profit measures. ${ }^{8}$

The fixed payoff, in the form of salary and other benefits is defined in our framework as a fixed amount of money, $F^{C}$ which is paid if the value of the firm's assets exceeds the value of its liabilities at their maturity. It is assumed that the equity-based compensation, as is common, is not fungible and that the executive must hold these securities till maturity (as in Ross 2004). The equity based compensation in our model is 
in the form of stock options. However, since the expiry date of the options are assumed to identical to the maturity date of the entire firm's liabilities their value is similar to compensation in the form of common stocks.

To calculate the fair value of the stock option, one needs to find the firm's value at which the holder of such an option is indifferent between exercising and not exercising the option. This problem was solved by Geske (1979) who used the Fourier transforms method. However, when the expiration date of the option and the stock are equal, as in our model, the Black and Scholes (1973) formula becomes a special case of the compound option formula and the strike price of this option is the sum of the face values of the claims with higher seniority and the striking price of the option, defined as $H$. Therefore by assuming that the executive compensation has the same maturity as the other liabilities, at time $T$, its payoff is equal to $\beta$ units of the maximum between zero and the difference between the financial institution's assets value and the sum of the face values of the deposits, the promised payment to the subordinated debt/ preferred stock holders and the predetermined strike price of the executive stock options. ${ }^{9}$ The payoff at expiry of the executive compensation, defined by $E_{T}$, can therefore be written as:

$$
E_{T}=\beta \max \left(V_{T}-F^{D}-F^{P}-H, 0\right)+F^{C} 1_{\left\{V_{T}>F^{D}+F^{P}\right\}}
$$

where $0 \leq \beta \leq 1$ is the number of common stocks that the executive can receive by exercising her options and $1_{\psi}$ is the indicator function of the event $\psi$. The current value of this position can be replicated by using two options: the first is a regular call option with a strike price of $F^{D}+F^{P}+H$ and the second is a cash-or-nothing call option, that 
pays a fixed amount of money at maturity if the value of the firm's assets is above the face value of the senior deposit and the commitment to the preferred stockholders. The intuition behind this term is that if the institution becomes insolvent the government deposit insurance fund or the debtholders will layoff the executive officer who would lose her fixed compensation.

The value of the executive's compensation and its sensitivity to various parameters can now be determined using standard option pricing theory. The current value of the executive's position can be written as:

$$
E=\beta \operatorname{Call}\left(T, F^{D}+F^{P}+H, V\right)+F^{C} \text { BinaryCall }\left(T, F^{D}+F^{P}, V\right)
$$

The general pricing equations for the call option and the binary call option can be expressed under the standard assumptions for risk-neutral contingent-claim valuation as:

$$
\begin{aligned}
& \operatorname{Call}(T, K, V)=e^{-r T}[V N(d(K)-K N(d(K)-\sigma \sqrt{T})] \\
& \operatorname{BinaryCall}(T, K, V)=e^{-r T} N(d(K)-\sigma \sqrt{T})
\end{aligned}
$$

where $\mathrm{N}()$ is the cumulative normal density and the function $d(K)$ is defined as:

$$
d(K)=\frac{\ln (V / K)+\left(r+\sigma^{2} / 2\right) T}{\sigma \sqrt{T}}
$$


By combining the values of the two options and the value of the traditional executive compensation, the fixed payments and equity based compensation, can be expressed as:

$$
\begin{aligned}
E= & \beta\left[V N\left(d\left(F^{D}+F^{P}+H\right)\right)-\left(F^{D}+F^{P}+H\right) e^{-r T} N\left(d\left(F^{D}+F^{P}+H\right)-\sigma \sqrt{T}\right)\right] \\
& +F^{C}\left(F^{D}+F^{P}\right) e^{-r T} N\left(d\left(F^{D}+F^{P}\right)-\sigma \sqrt{T}\right)
\end{aligned}
$$

When $F^{p}$ is equal to zero, the pricing equation becomes a special case where there are no government or privately owned preferred stocks.

The most interesting parameter of the model is risk, which enters the option pricing formula in the form of volatility. If the executive can decide what would be the riskiness of the firms assets she would choose the volatility level that maximizes the value of her compensation. The impact of a change in volatility on the value of the executive's compensation can now be found by taking the derivative of $E$ w.r.t. $\sigma$ :

$$
\begin{aligned}
\frac{\partial E}{\partial \sigma}= & \beta V N^{\prime}\left(d\left(F^{D}+F^{P}+H\right) \sqrt{T}-\right. \\
& F^{C} d\left(F^{D}+F^{P}\right) \mathrm{e}^{-\mathrm{rT}} N^{\prime}\left(\sigma \sqrt{T}-d\left(F^{D}+F^{P}\right)\right) / \sigma
\end{aligned}
$$

where $N^{\prime}(X)=e^{-x^{2 / 2}} / \sqrt{2 \pi}$. While the sensitivity of the option based compensation to assets risk is always positive (the first expression on the R.H.S of the equation) the cashor-nothing call option sensitivity to assets risk is always negative if the option is in the money since default has not occurred. Therefore, the executive's risk incentive is an increasing function of the value of the option-based compensation and a decreasing function of the value of the fixed cash benefit. To analyze optimal risk taking by 
executives we consider in the next section two states of the world: "good times" when the value of the assets of the financial firm far exceeds the value of its liabilities and "bad times".

\section{Analyzing executive compensation and incentives in good and bad}

\section{times}

In these two states of nature the relative values of the two compensation components changes and as a result so does the executive's risk taking behavior.

\subsection{Executive compensation and incentives in good times (2004-2007 bubble)}

We assume that the executives' objectives do not necessarily coincide with firm value maximization when the financial institution is leveraged (See Chesney and Gibson-Asner 2001 and Sundaram and Yermack 2008) and their main objective is to maximize the value of their claims. Henceforth, the executives would choose an optimal volatility for the firms' assets that maximize the value of their compensation.

In good times the value of the assets of the financial institution is assumed to be far above the value of its liabilities. We can therefore set: $V=\gamma\left(F^{D}+F^{P}\right)$ where $\gamma \geq 1$ is the inverse of the leverage ratio. Since the stockholders have a call option on the value of the firm's assets the value of their holdings would increase with assets volatility See Jensen and Meckling 1976 and Galai and Masulis 1976). However, the executives' incentive may differ from stockholders motivation due to their fixed compensation and therefore stockholders have a strong incentive to mitigate the negative risk taking 
motivation that is created by the executive's fixed compensation by increasing the amount of equity based component hold by the executives. This wealth transfer effect exists mostly in the context of the banking industry since depositors (and deposit insurance funds) cannot perfectly monitor the actions of stockholders (Saunders et al. 1990)

Figures 1 presents the value of the executive compensation, when the ratio between the amounts of fixed compensation (the parameter $F^{C}$ ) and the units of option based compensation (the parameter $\beta$ ) is relatively high and equal to 2.5 , for different levels of assets volatility and leverage. In this example, the volatility levels can vary between $5 \%$ and $35 \%$, time to maturity is set at one year and the risk free rate is $5 \%$. The executive stock compensation is in the form of a simple call option with a strike price of 0.25 , which means that the option can be exercised above the current value of assets when $\gamma=1.35$. Figure 1 shows that under any level of volatility, if the firm remains solvent, the value of the executive compensation is a decreasing function of assets volatility. Therefore, the executive has a strong incentive to reduce assets volatility as much as possible.

The stockholders effort to align the executive payoff with their risk profile would end up in an increasing ratio of equity based compensation to fixed compensation. Figure 2 presents the value of the executive compensation when the ratio between the amounts of fixed compensation and the units of option based compensation is relatively low and equal to 0.4 . When assets values are relatively high and the parameter $\gamma$ is above 1.21 the value of the executive compensation increases with the level of assets volatility. Therefore, under such conditions executives in financial institutions have strong 
motivation to implement actions that would increase assets risk. The phenomenon, of increased equity based compensation accompanied by increased level of assets risk was observed in the US between 2004 and 2007 (See Bebchuk and Grinstein 2005). Major investments firms and commercial banks invested in subprime mortgages and other risky assets as CDOs and CDSs which where relatively new instruments.

\subsection{Executive compensation and incentives in bad times (2007-2009 financial crisis)}

The 2007-2009 financial crisis was characterized by a sharp decrease in the value of the assets of the financial sector's assets and consequently a sharp decline in the share prices of many financial institutions. Some of these institutions were forced to sell themselves, some went into bankruptcy and others were bailed out by the U.S. government. The crisis first caused to a credit crunch and then to a credit freeze when financial institutions stopped lending even to each other. To unlock the credit markets the U.S. Treasury and the Federal Reserve injected huge sums of money into the system and also guaranteed a large part of the credit market. Implicit in these government efforts was the assumption that the credit crisis is mainly a result of an insufficient supply of funds. Despite these massive government efforts financial institutions have not resumed lending and increased their holdings of riskless assets. ${ }^{10}$ As can be seen in Figure 2, the fall in assets value (low level of $\gamma$ ) due to the crisis resulted in the executives having a negative incentive to take risks since the value of their compensation is maximized under low assets risk. This can explain why the various plans of the U.S. Treasury and Federal Reserve of supplying liquidity to financial institutions have been ineffective in thawing the freeze in the credit 
markets. Executives had little motivation to substitute the relatively low risk government debt with risky credit to businesses and households.

The fact that under any level of leverage the executive optimal decision would be to choose between two extreme solutions is shown in Figure 3, where the value of the executive compensations versus assets risk is presented for different levels of leverage. For high levels of $\gamma$ the executive would choose the highest possible level of risk and for low $\gamma$ levels the executive would choose lower levels of risk.

Figure 4 presents the total value of the executive compensation as well as the value of the fixed and equity based compensation for different levels of assets volatility. Figure 4 highlights the fact that the executive payoff function is a concave function of assets risk and therefore the executives would choose either a high level of risk which increases the risk of default of the financial institution and can cause systemic risk for the economy, or avoid taking any risk at all, a solution that can cause a severe liquidity crisis for the real sector of the economy. Moreover, the restrictions on option pay under TARP where financial institutions are not allowed to deduct for tax purposes senior executive compensation in excess of $\$ 500,000$ for each senior executive would make the problem even worse. Such restrictions would further reduce the quantity of equity based compensation and thereby give a stronger incentive to the executive to avoid risk.

\section{New terms for executive compensation}

This section presents a new structure for executive compensation that counters to the existing compensation scheme, motivates the executive to take moderate levels of assets risk and therefore enhances financial stability. It may help avoid future crises and speed 
up financial recovery by eliminating the incentive for corner solutions for risk taking by the executives of financial institutions.

The proposed executive compensation scheme includes, as before a cash (fixed) payment that is paid as long as the company is solvent, an option-based compensation and a new type of compensation in the form of a fixed payment, $F^{M}$. This amount is paid at maturity if the value of the firm's assets is between two thresholds, denoted $H^{L}$ and $H^{H}$ respectively, which are located above the current value of the firm's assets. If however, at expiry the value of the firm's assets is outside of this range the executive's payoff is zero.

The newly suggested component of the executive compensation has an identical payoff as that of a combination of a long binary call option that pays a fixed amount of money at maturity if the value of assets is above some threshold, defined as $H^{L} \geq V$, and a short position at a similar option with a higher strike price $H^{H} \geq H^{L} \geq V$. The value of this compensation is bell-shaped with respect to assets volatility. Therefore, due to the convex relationship between the total value of the two options and volatility, their maximum would be reached at some moderate level of volatility and not in one of the corner solutions of zero or infinity. Under the suggested compensation, if the executive has the ability to choose the level of volatility she would prefer an intermediate level of volatility that would maximize the value of her compensation.

The payoff at expiry of the new suggested executive compensation $E_{T}^{*}$ can be written as: 


$$
E_{T}^{*}=\beta \max \left(V_{T}-F^{D}-F^{P}-H, 0\right)+F^{C} 1_{\left\{V_{T}>F^{D}+F^{P}\right\}}+F^{M} 1_{\left\{H^{H}>V_{T}>H^{L}\right\}}
$$

The third term on the RHS of equation (6) is the payoff due to the suggested new component of executive compensation that can be priced as a pair of binary call options with different strikes. Therefore the option equivalent of the total value of the executive compensation can be written as

$$
\begin{aligned}
E^{*}= & \beta \operatorname{Call}\left(T, F^{D}+F^{P}+H, V\right)+F^{C} \text { BinaryCall }\left(T, F^{D}+F^{P}, V\right) \\
& +F^{M}\left[\text { BinaryCall }\left(T, F^{D}+F^{P}+H^{L}, V\right)\right. \\
& \left.- \text { BinaryCall }\left(T, F^{D}+F^{P}+H^{H}, V\right)\right]
\end{aligned}
$$

This can be written as:

$$
\begin{aligned}
E^{*}= & \beta\left[V N\left(d\left(F^{D}+F^{P}+H\right)\right)\right. \\
& \left.+\left(F^{D}+F^{P}+H\right) e^{-r T} N\left(d\left(F^{D}+F^{P}+H\right)-\sigma \sqrt{T}\right)\right) \\
& +F^{C}\left(F^{D}+F^{P}\right) e^{-r T} N\left(d\left(F^{D}+F^{P}\right)-\sigma \sqrt{T}\right) \\
& +F^{M}\left[\left(F^{D}+F^{P}+H^{L}\right) e^{-r T} N\left(d\left(F^{D}+F^{P}+H^{L}\right)-\sigma \sqrt{T}\right)\right. \\
& -F^{M}\left[\left(F^{D}+F^{P}+H^{H}\right) e^{-r T} N\left(d\left(F^{D}+F^{P}+H^{H}\right)-\sigma \sqrt{T}\right)\right.
\end{aligned}
$$

The sensitivity of the new executive component to assets risk can be found in two steps: first, we calculate the sensitivity of the new component to assets risk and then we can set to zero (or to reduce to a negligible level) the sensitivity to assets risk of the value of the two other components of executive compensation by monitoring their quantities. This is possible due to their offsetting sensitivity to assets risk. Therefore, only the 
sensitivity of the new component of executive compensation to risk needs to be analyzed, and the sensitivity to assets volatility is derived as follows:

$$
\begin{aligned}
\frac{\partial E^{*}}{\partial \sigma}= & F^{M} d\left(F^{D}+F^{P}+H^{L}\right) \mathrm{e}^{-\mathrm{rT}} N^{\prime}\left(\sigma \sqrt{T}-d\left(F^{D}+F^{P}+H^{L}\right)\right) / \sigma \\
& -F^{M} d\left(F^{D}+F^{P}+H^{H}\right) \mathrm{e}^{-\mathrm{rT}} N^{\prime}\left(\sigma \sqrt{T}-d\left(F^{D}+F^{P}+H^{H}\right)\right) / \sigma
\end{aligned}
$$

The value of the long call cash-or-nothing option with the low strike price, the first term on the RHS of equation (9), decreases with assets volatility, whereas the value of the short call cash-or-nothing option with the high strike increases with assets volatility. These two options which are both "out of the money" have opposing impacts on the value of the total executive compensation and therefore its value reaches the maximum at some intermediate level of risk. Executives would try to maximize their compensation by finding the volatility level that maximizes compensation such that:

$$
\frac{\partial E^{*}}{\partial \sigma} \mid \sigma=\sigma^{*}=0 \text { while } \frac{\partial^{2} E^{*}}{\partial \sigma^{2}}<0
$$

Equation (10) is solved numerically, in the absence of a closed form solution, to illustrate the impact of the executive's "constrained" maximization on the choice of investment policy and thus on risk incentives.

The main results are, first, if there is a fixed compensation $F^{M}$ with a payoff that is above the market value of the firm's assets there will be an interior solution for the 
optimal volatility. This is unlike the Black-Scholes- Merton equity pricing result, where as assets risk increases, the value of shareholders' wealth increases as well. Figure 5 presents the value of the executive compensation versus leverage ratios for different levels of volatility. The new compensation scheme entitles the executive to receive a compensation which is 3.5 times greater than the fixed payoff if the value of the stock by the end of the year is between 0.15 and 0.45 . This is equivalent to receiving the same payment if the value of the firm's assets is between 1.25 and 1.45 . It can be seen that at time 0 , if the leverage ratio is relatively moderate, where the parameter $\gamma$ is between 1.06 and 1.22 , the executive can maximize the value of her compensation by choosing a moderate volatility level of $25 \%$. Second, as the firm's leverage decreases the optimal volatility level would decrease. Figure 6 presents the volatility level that maximizes the executive compensation for different leverage ratios. When $\gamma=1.1$ the optimal volatility level is $18 \%$ whereas when the leverage ratio decreases and $\gamma$ is set equal to 1.2 and 1.3 respectively the optimal volatility is equal to $14 \%$ and $11 \%$ respectively.

Third, as the lower threshold, $H^{L}$ (the value of assets have to be above it at maturity for executives to receive their fixed payment, $F^{M}$ ), increases, the optimal value of volatility increases as well. Finally, as the upper threshold, $H^{L}$ (the value of assets have to be below it at maturity for executives to get $F^{M}$ ), increases, the optimal value of volatility is increases as well. Table 1 presents the optimal volatility value when $\gamma=1.1$ for different lower and upper levels of threshold ranges. When the fixed compensation is paid at maturity only if the value of assets at maturity is between 1.15 and 1.20 the optimal volatility level is equal to only $6.44 \%$. However, when the "payoff window" is shifted to the levels between 1.30 and 1.35 the optimal volatility is equal to $14.07 \%$. 
Furthermore, when the payoff window at which the fixed compensation upon maturity is paid is widened and located between 1.30 and 1.60 the optimal volatility level is equal $25.95 \%$. In the extreme case, when a fixed compensation would be paid at maturity at any assets value which is above 1.3 , the optimal volatility level is equal $57.80 \%$. The implication is that a policymaker (regulator), who wants to restrict the volatility of the financial institution's assets, can set an upper and a lower level for the moneyness of the compensation and thus determine the range of asset volatility that the executives would choose.

\section{Summary}

The 2007-2009 financial crisis was caused by a number of factors, one of which was excessive risk taking by financial institutions. The increased motivation for risk taking can be explained by the rapid growth of equity based executive compensation in recent years. The paper first analyzes an executive compensation structure that is composed of a fixed cash payment which is paid unless the firm is insolvent and an equity based compensation in the form of executive stock options.

We first show that under relatively low levels of leverage the total value of a compensation that is dominated by equity based compensation is maximized by choosing the highest possible level of assets risk and can therefore lead to excessive risk taking.

The next step analyzes the same compensation structure but with a high levels of leverage (low assets values) where the fixed compensation is the dominant component. Under such circumstances the rational executives will choose the lowest possible level of assets risk since this maximizes the value of their compensation. In the past, stockholders 
could restore the executive incentives for taking risk, in a manner that is aligned with their interests by increasing the size of the equity based compensation. However under the current regulations and trends in corporate governance they are more limited in doing so. Therefore, the existing executive compensation scheme leads to a concave relationship between assets risk and the value of the compensation and creates an incentive for the executive to choose corner solutions, that either lead to an excessive risk taking or to a freeze out of the lending activity to the public.

The major contribution here is a proposed new component for executive compensation that leads to an interior solution of risk taking. The component is paid only if the value of the firm's assets is within a predetermined range of assets value at expiration. This new form of compensation creates a convex relationship between assets risk and the value of the compensation. 


\section{References}

Agrawal, A., and G., Mandelker, 1987, Managerial incentives and corporate investment and financing decisions, Journal of Finance 42(4), 823-837.

Barclay, M.J., and C., Smith, 1995, The maturity structure of corporate debt, Journal of Finance 50, 609-631.

Barnea, A., R.A., Haugen, and L.W., Senbet, 1980, A rationale for debt maturity structure and call provisions in an agency theoretic framework, Journal of Finance 35, 1223-1234.

Basel Committee on Banking Supervision, 2004, International Convergence of Capital Measurement and Capital Standards, BIS.

Basel Committee on Banking Supervision, 2005, 1996 Amendment to the Capital Accord to Incorporate Market Risks, BIS.

Bebchuk, L.A, and R. Jackson, 2005, Executive Pensions, Journal of Corporation Law 30, 823-855.

Bebchuk, L.A., and Y., Grinstein, 2005, The Growth of executive pay, Oxford Review of Economic Policy 21, 283-303.

Black, F., and M., Scholes, 1973, The pricing of options and corporate liabilities, Journal of Political Economy 81, 637-654.

Carpenter, J.N., 2000, Does option compensation increase managerial risk appetite?, Journal of Finance, 55, 2311-2331

Chakraborty, A ,S. Sheikh ,N. Subramanian, 2007, Termination risk and managerial risk taking, Journal of Corporate Finance ,13,170-188

Chen, C., T.L., Steiner, and A.M., Whyte, 2006, Does stock option-based executive compensation induce risk-taking? An analysis of the banking industry, Journal of Banking and Finance 30, 915-945.

Chesney, M., and R., Gibson-Asner, 2001, Reducing asset substitution with warrant and convertible debt issues, Journal of Derivatives 9, 39-52.

Coles J., N., Daniel and N., Naveen, 2008, Boards: Does one size fit all?, Journal of Financial Economics 87 (2), 329-356.

Diamond, D.W., 1989, Reputation acquisition in debt markets, Journal of Political Economy 97, 828-862. 
Diamond, D.W., 1991, Monitoring and reputation: The choice between bank loans and directly placed debt, Journal of Political Economy 99, 689-721.

DeFusco, R., R., Johnson, and T., Zorn, 1990, The effect of executive stock option plans on stockholders and bondholders, Journal of Finance 45(2), 617-627.

Gabaix, X., and A., Landier, 2008, Why has CEO pay increased so much?, Quarterly Journal of Economics, 123, 49-100.

Galai, D. and Masulis, R., 1976, The option pricing model and the risk factor of stock, Journal of Financial Economics 3, 631-44.

Gerakos, J., 2007, CEO pensions: disclosure, executive power, and optimal contracting, Working Paper, Wharton School of Management.

Geske, R., 1979, The Valuation of compound options, Journal of Financial Economics, 7, 63-81. .

Green R., 1984, Investment incentives, debt and warrants, Journal of Financial Economics 13, 115-135.

Guay, W.R., 1999, The sensitivity of CEO wealth to equity risk: An analysis of the magnitude and determinants, Journal of Financial Economics 53, 43-71.

Guedes, J., and T., Opler, 1996, The determinants of the maturity of corporate debt issues, Journal of Finance 51, 1809-1833.

Hall, B.J., 1998, The pay to performance incentives created by executive stock options, NBER Working Paper.

Hall, B., and K., Murphy, 2003, The trouble with stock options, Journal of Economic Perspectives 17, 49-70.

Hirshleifer, D., and R., Suh, 1992, Risk, managerial effort, and project choice, Journal of Financial Intermediation 2, 308-345.

Hirshleifer, D. and A. Thakor, 1992, Executive conservatism, project choice, and debt, Review of Financial Studies 5, 437-470.

Merton, R.C., 1974, On the pricing of corporate debt: the risk structure of interest rates, Journal of Finance 29, 449-470.

Ross, S., 2004, Compensation, incentives, and the duality of risk aversion and riskiness. Journal of Finance 59, 207-225. 
Saunders, A., Strock, F., Travlos, N., 1990, Ownership structure, deregulation and bank risk-taking, Journal of Finance 45, 643-654.

Smith, C., and J., Warner, 1979, On Financial Contracting: An Analysis of Bond Covenants, Journal of Financial Economics 7, 117-130.

Sundaram, R., and D. Yermack, 2007, Pay Me Later: Inside Debt and Its Role in Managerial Compensation, Journal of Finance 62, 1551-1588. 
Table 1: The Optimal volatility in the presence of the new executive compensation

This table presents the optimal volatility level in percentages that maximizes the value of the executive compensation for different values of $H^{L}$ and $H^{H}$, the two thresholds denoting the range of firm's value at maturity for the executive to receive a fixed compensation of $F^{M}$. All the other data are the same as in Figure 1. We assume that the leverage ratio $\gamma$ is assumed to equal to 1.1 .

\begin{tabular}{|c|c|c|c|c|c|c|c|c|c|}
\hline \multirow{2}{*}{$\begin{array}{c}\underline{H}^{L} \\
\text { Values }\end{array}$} & \multicolumn{9}{|c|}{$\underline{H^{H} \text { Values }}$} \\
\hline & 1.20 & 1.25 & 1.30 & 1.35 & 1.40 & 1.45 & 1.50 & 1.55 & 1.60 \\
\hline 1.15 & 6.44 & 8.21 & 9.81 & 11.28 & 12.64 & 13.91 & 15.09 & 16.19 & 17.23 \\
\hline 1.20 & & 10.65 & 12.43 & 14.07 & 15.59 & 17.01 & 18.33 & 19.58 & 20.76 \\
\hline 1.25 & & - & 12.43 & 14.07 & 18.02 & 19.53 & 20.95 & 22.28 & 23.54 \\
\hline 1.30 & & - & - & 18.48 & 20.17 & 21.75 & 23.24 & 24.63 & 25.95 \\
\hline 1.35 & & - & - & - & 22.13 & 23.77 & 25.31 & 26.76 & 28.13 \\
\hline 1.40 & & - & - & - & - & 25.64 & 27.22 & 28.71 & 30.12 \\
\hline 1.45 & & - & - & - & - & - & 29.00 & 30.52 & 31.97 \\
\hline 1.50 & & - & - & - & - & - & - & 32.22 & 33.70 \\
\hline 1.55 & & & & & & & & & 35.32 \\
\hline
\end{tabular}




\section{Figure 1: Executive compensation versus leverage for different levels of}

\section{assets risk and a high ratio between fixed and variable compensations}

This figure presents the total value of the executive compensation according to the option based method, where the ratio between the amount of fixed compensation and the notional amount of the option based compensation is equal to 2.5. The time horizon, $T$, is equal to 1 , the risk free rate $r$ is $5 \%$, and assets volatility is set at different values of $5 \%, 15 \%, 25 \%$ and $35 \%$. The leverage ratio, which is defined by $V=\gamma\left(F^{C}+F^{P}\right)$, where $V$ is/ the current value of the firm assets and $F^{C^{\prime}}$ and $F^{P^{\prime}}$ are the face value of the senior deposits and the subordinated debt or the preferred stocks respectively, has values between 0.7 and 1.75 . The executive equity based compensation is in the form of a call option on the firm assets with a strike price which is equal to $\gamma=1.35$

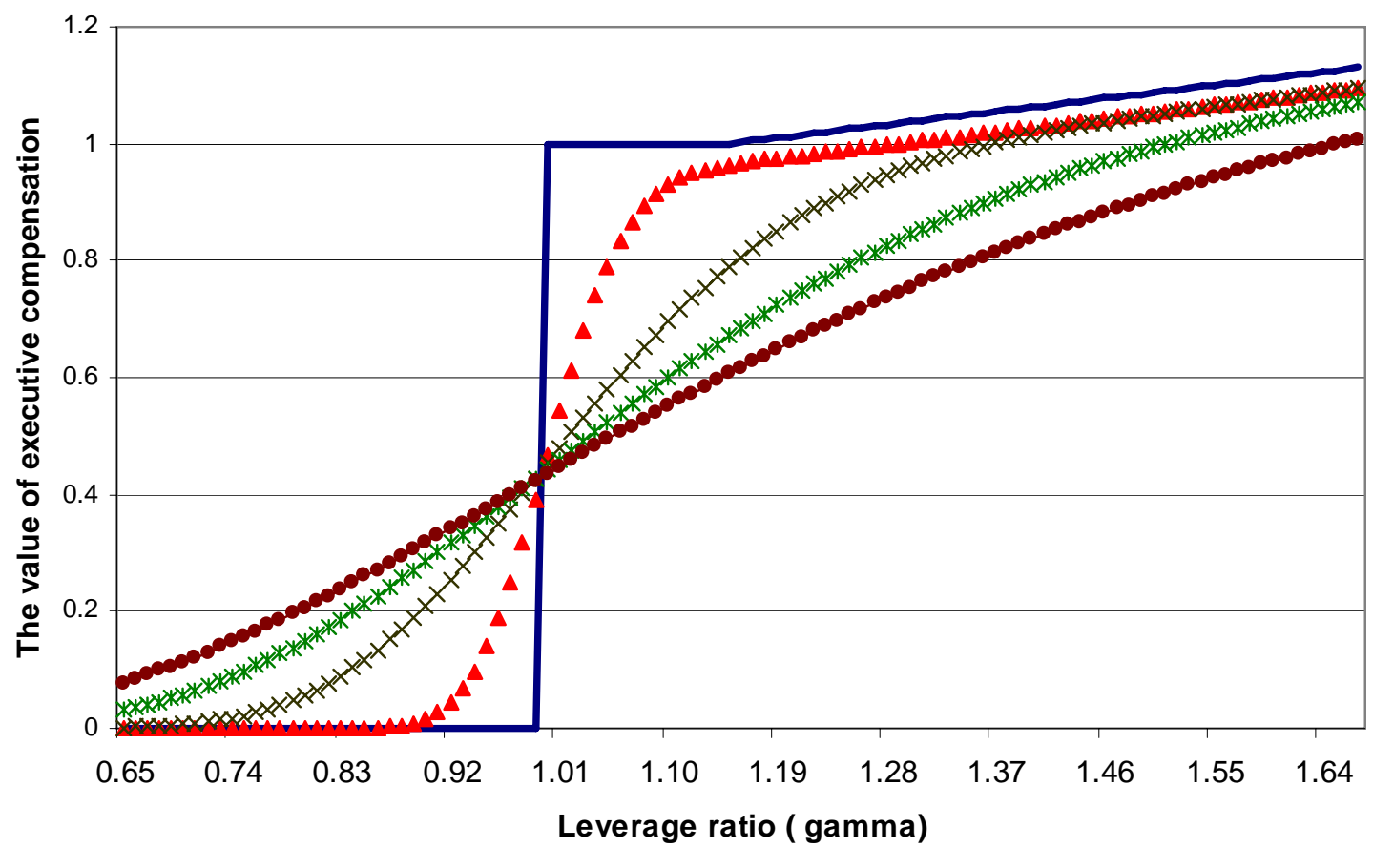

The executive payoff $\triangle$ vol $=5 \% \quad \times$ vol $=15 \% \quad *$ vol $=25 \% \multimap$ vol $=35 \%$ 


\section{Figure 2: Executive compensation versus leverage for different levels of}

assets risk and a low ratio between fixed and variable compensation

This figure presents the total value of the executive holding according to the option based method, where the ratio between the amount of fixed payment and the notional amount of the option based compensation is equal to 0.4. All the other data are the same as in Figure (1).

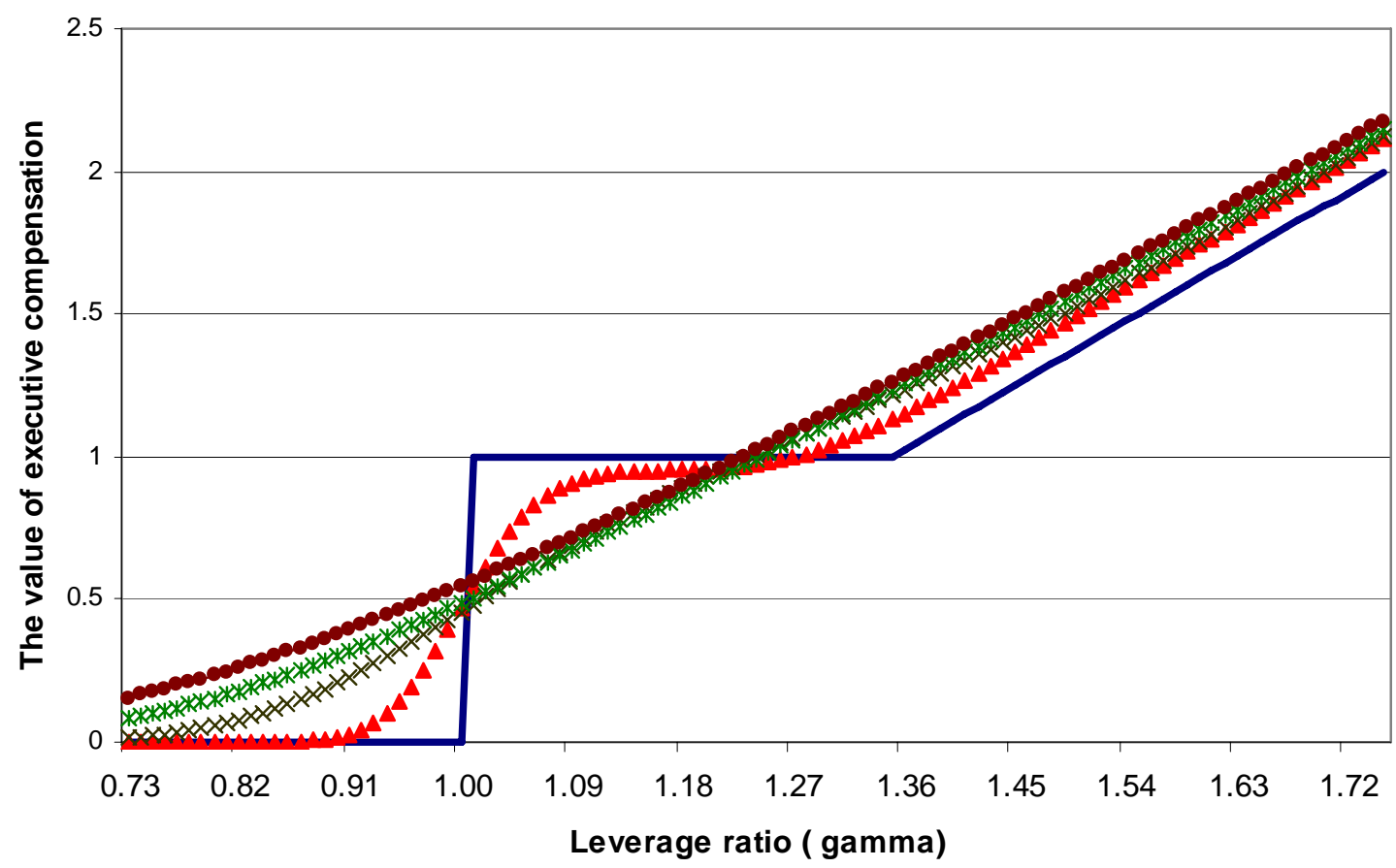

The executive payoff $\Delta$ vol=5\% $\times$ vol $=15 \% \quad *$ vol $=25 \% \multimap-$ vol $=35 \%$ 


\section{Figure 3: Executive compensation versus assets risk leverage for different leverage levels and a low ratio between fixed and variable compensation}

This figure presents the total value of the executive compensation according to the option based method, where the ratio between the amount of fixed compensation and the notional amount of the option based compensation is equal to 0.4 . The leverage ratio, defined by $V=\gamma\left(F^{C}+F^{P}\right)$, where $V$ is the current value of the firm assets and $F^{C^{\prime}}$ and $F^{P^{\prime}}$ are the face value of the senior deposits and the subordinated debt or the preferred stocks respectively, takes on values of $\gamma=1,1.1,1.2,1.3$ and 1.4. Assets volatility can vary between $1 \%$ and $70 \%$.

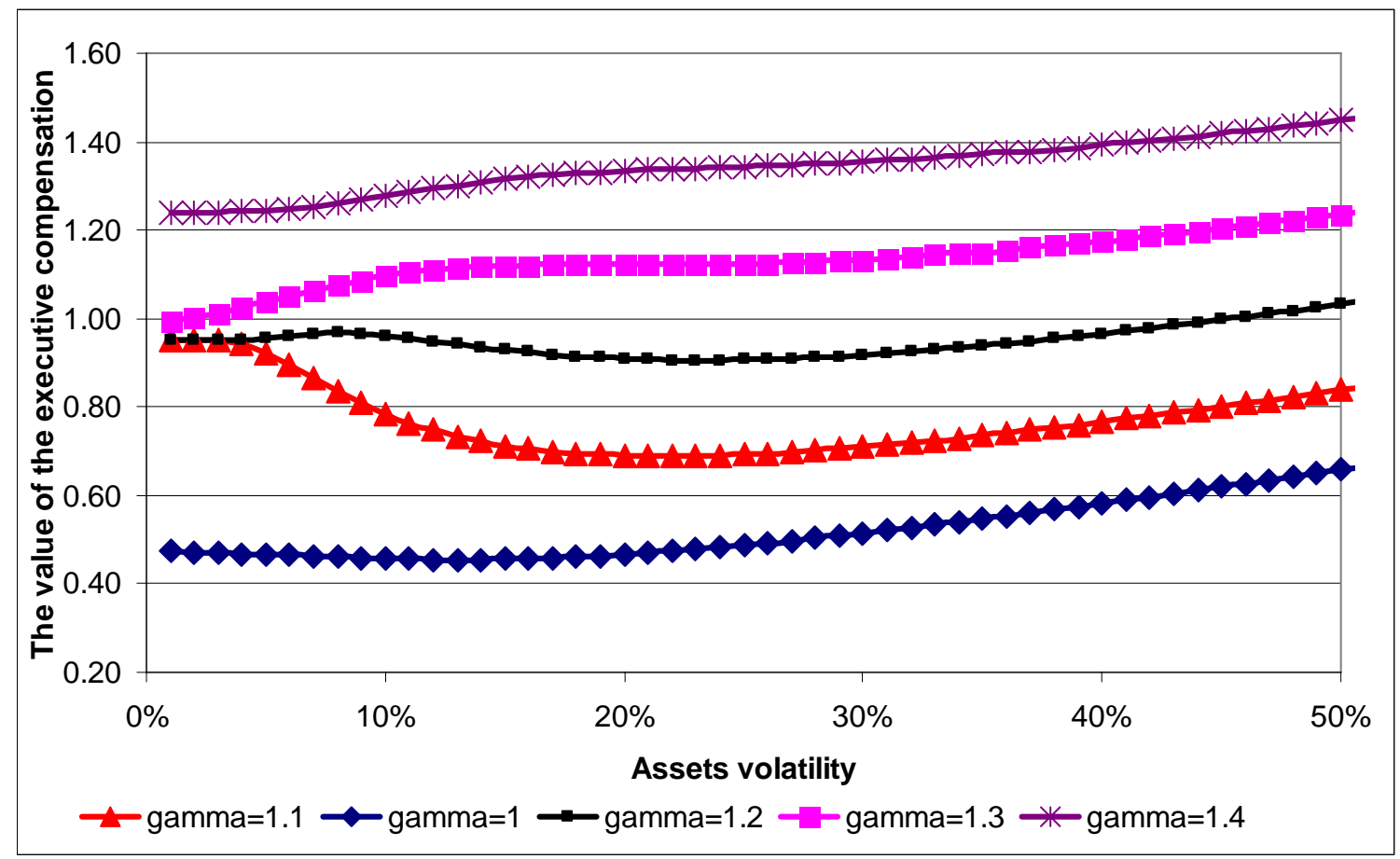




\section{Figure 4: Equity-based compensation, the fixed compensation and the total value of the executive compensation versus assets risk}

This figure presents the total value of the executive compensation, the equity based compensation and the fixed value compensation according to the option based method, where the ratio between the amount of fixed compensation and the notional amount of the option base compensation is equal to 0.4. The leverage ratio, defined by $V=\gamma\left(F^{C}+F^{P}\right)$, equals to $\gamma=1.1$ and assets volatility varies between $1 \%$ and $50 \%$.

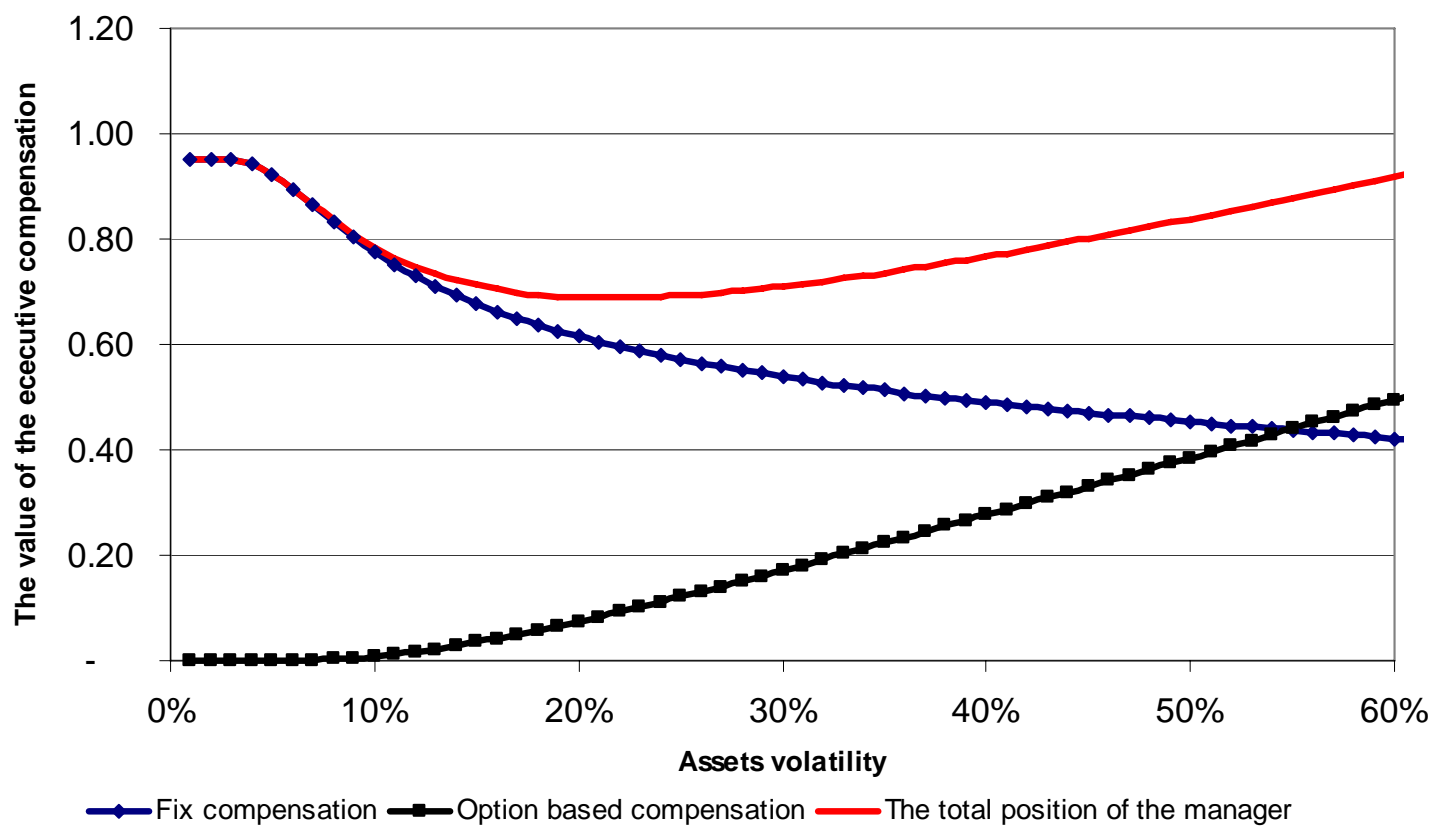




\section{Figure 5: New Executive compensation versus leverage for different}

\section{levels of assets risk}

This figure presents the total value of the executive holding according to the new suggested compensation. The ratio between the amount of fixed compensation and the notional amount of the option base compensation is equal to 2.5 . The time horizon, $T$, is equal to1 year, the risk free rate $r 5 \%$, assets volatility is given values of $5 \%, 15 \%, 25 \%$ and $35 \%$. The executive receives an extra compensation that is three times greater than the fixed payment if at maturity the value of the stock price is between 0.15 and 0.35 , which is equivalent to assets value between 1.25 and 1.45 . The executive equity based compensation is in the form of a call option on the firm assets with a strike price equal to $\gamma=1.35$

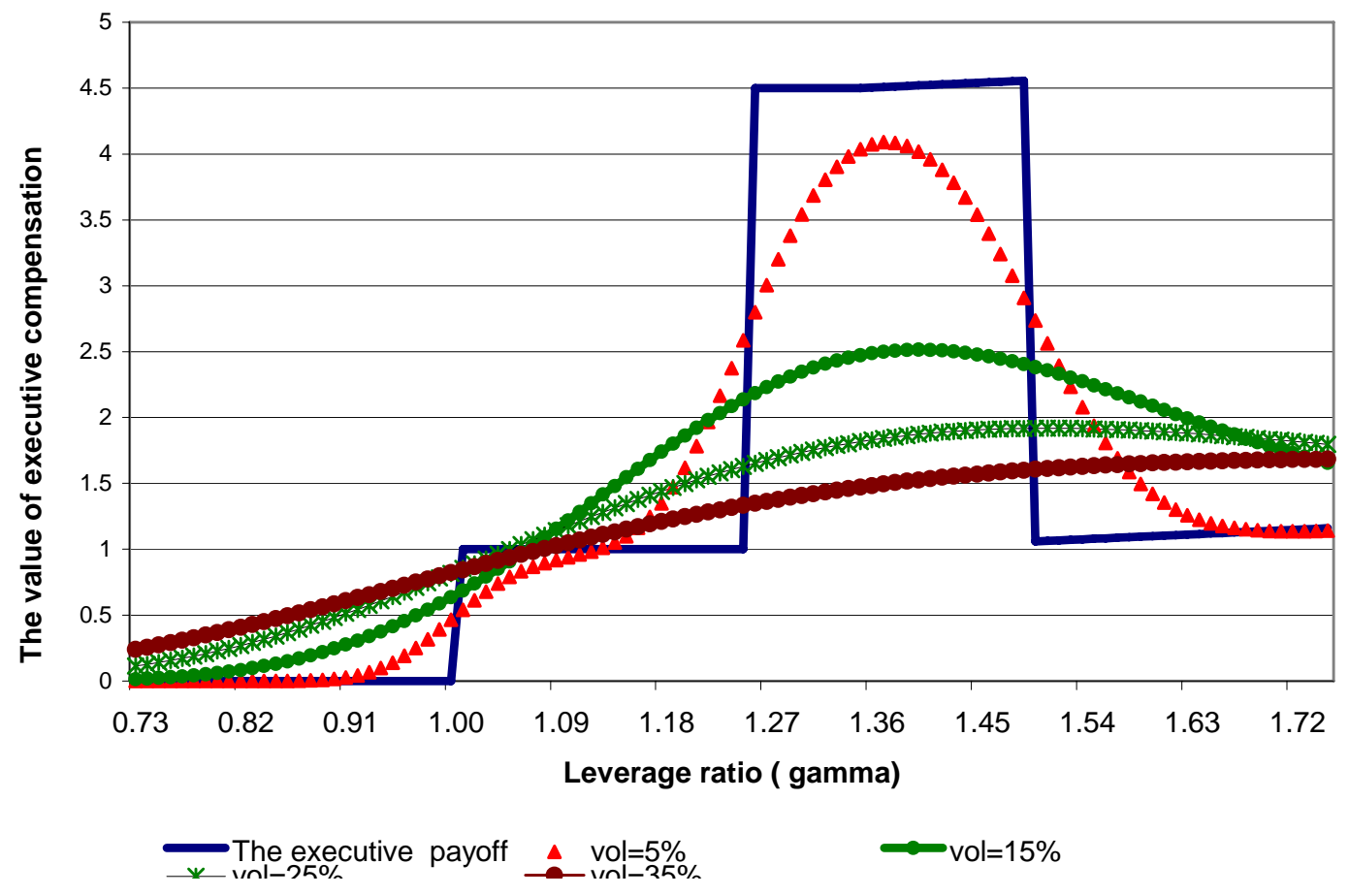


Figure 6: New Executive compensation versus assets volatility for

\section{different levels of leverage.}

This figure presents the total value of the executive compensation according to the new suggested compensation. The leverage ratio, as measured by the ratio between assets and the face value of debt is equal 1.1,1.2 and 1.3. All the other data are the same as in Figure 5.

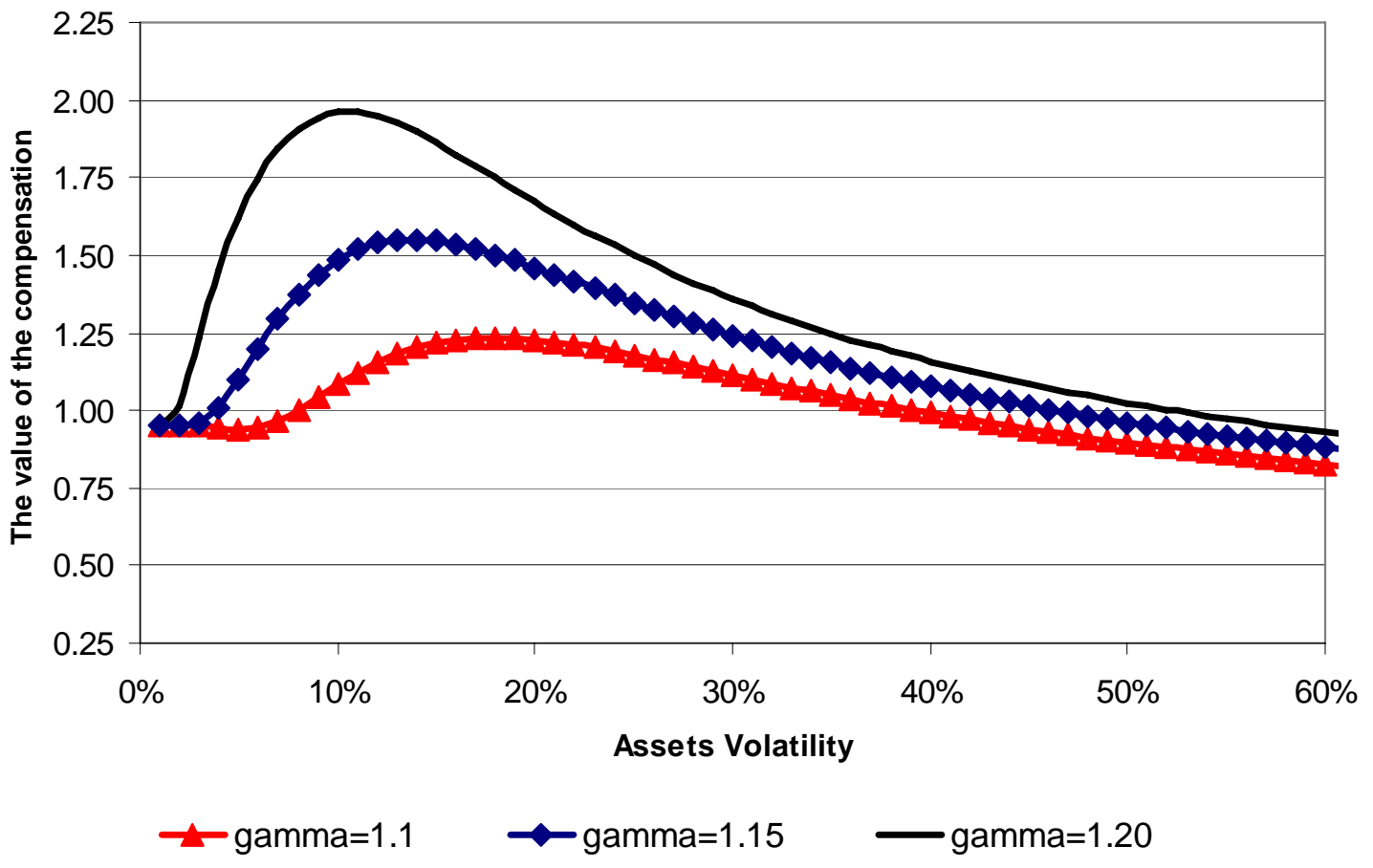




\section{Endnotes}

${ }^{1}$ The accords of Basel I (1998), Basel II (2004) and Basel Market Risk (2005).

2 Deviations from the assumption of a positive relationship between assets risk and the value of the executive compensation were made by Carpenter (2000), who assumed that the manager is risk averse and can not hedge his executive option and by Hall (1998), who argues that the affect of option grants on CEO risk-taking is a function of the CEO's risk aversion, which in turn depends on his wealth and other factors.

3 The largest stimulus programs are the following: Term Auction Facility (TAF) (12/07) with Federal Reserve lending to commercial banks and MBS used as collateral $\$ 2.9$ trillion allocated, and spent $\$ 469$ billion; the Troubled Asset Relief Program (TARP) $(10 / 08)$ with U.S. Treasury injection of capital and bailouts, purchase of toxic assets, $\$ 700$ billion allocated, and \$323 billion spent; the Term Asset-Backed Securities Loan Facility (TALF) (11/08) with the purchase of assets backed consumer loans, $\$ 1$ trillion allocated; the FDIC Temporary Liquidity Guarantee Program (11/08) of new bank issued bonds, with \$1.5 trillion allocated and \$297 billion spent as of February 2009.

${ }^{4}$ As an example, on November 20 2008, Rep. Barney Frank (D-Mass.), the chairman of the House Financial Services Committee, has mentioned that the Treasury's rules could run counter to the efforts of corporate-governance activists, who have sought in recent years to link CEO pay to the company's performance.

${ }^{5}$ See the Accountability for the Troubled Asset Relief Program: The Second Report of the Congressional Oversight Panel January 9, 2009. American Express, Bank of America, Goldman Sachs and Morgan Stanley are among big institutions that reported a sharp rise in their holdings of cash and easy-to-sell securities in the first quarter of 2009.

${ }^{6}$ There is empirical evidence of the inhibiting effect of termination risk on managerial risk taking that offsets the positive effect of the convexity of managerial compensation. However termination risk is in general exogenous and cannot be use as a form of compensation (Chakraborty et al 2007).

${ }^{7}$ To keep the notation as simple as possible, all variables without subscripts are present values. 
${ }^{8}$ The cash payoff includes salary, bonus and other benefits. However, recent empirical studies (Bebchuk and Jackson 2005, Sundaram and Yermack 2007, and Gerakos 2007) have found that U.S. CEOs hold substantial defined benefit pensions that yield an equal claim with other creditors in bankruptcy, and thus constitute inside debt. The affect of these claims on the risk-taking motivation of the managers can be offset or eliminate by the reputation effect of the bankrupt company as described by Hirshleifer and Thakor (1992).

${ }^{9}$ We assume that in the case of executive stock option the dilution effect is relatively small and has only a secondary effect on the other liabilities issued by the financial institution.

${ }^{10}$ U.S. depository institutions reduced net loans from $60.3 \%$ of total assets in $12 / 31 / 2006$ to $55.6 \%$ in $12 / 31 / 2008$, in the same periods their cash holdings doubled from $4 \%$ to $8 \%$. 